\title{
Upaya Meningkatkan Kemampuan Motorik Halus Anak Melalui Kegiatan Membatik Jumputan
}

\author{
Sohibah Darojatur Rofiah ${ }^{1}$, Hilman Mangkuwibawa ${ }^{2}$ \\ 1,2, Pendidikan Islam Anak Usia Dini \\ Universitas Islam Negeri Sunan Gunung Djati Bandung \\ Email:sohibah613@gmail.com ${ }^{1}$, hilmanmangkuwibawa@gmail.com² \\ Naskah diterima: 13 November 2019, direvisi: 28 Februari 2020, diterbitkan: 31 Maret 2020
}

\begin{abstract}
Abstrak
Penelitian ini bertujuan untuk mengetahui kemampuan motorik halus anak sebelum menggunakan kegiatan membatik jumputan, untuk mengetahui proses pembelajaran pada anak ketika menggunakan kegiatan membatik jumputan, untuk mengetahui kemampuan motorik halus anak setelah menggunakan kegiatan membatik jumputan setiap siklus. Metode penelitian ini menggunakan metode penelitian tindakan kelas (PTK) dengan pendekatan campuran. Subjek penelitian ini adalah kelompok B RA Annur Pungangan Kab. Subang sebanyak 30 orang siswa. Teknik pengumpulan data dalam penelitian ini menggunakan lembar observasi aktivitas guru dan siswa, lembar observasi kemampuan motorik halus, dan dokumentasi. Berdasarkan penelitian tindakan kelas yang dilakukan di RA Annur pungangan Kab. Subang, maka dapat disimpulkan bahwa kemampuan motorik halus anak sebelum penerapan kegiatan membatik jumputan dengan kriteria kurang sekali. Adapun pada siklus I memperoleh nilai rata-rata sebesar 49,43 dengan kriteria kurang sekali ternyata mengalami peningkatan di siklus II memperoleh nilai rata-rata sebesar 74,23 dengan kriteria baik. Berdasarkan hasil penelitian terbukti bahwa ketercapaian siswa dengan menggunakan kegiatan membatik jumputan dapat meningkatkan kemampuan motorik halus anak
\end{abstract}

Kata kunci: anak, membatik jumputan, motorik halus

\begin{abstract}
This study aims to determine the fine motor skills of children before using activities membatik jumputan, to determine the learning process in children when using jumputan batik activities, to determine the child's fine motor skills after using jump batik making activities each cycle. This research method uses the classroom action research (CAR) method with a mixed approach. The subject of this research is group $B$
\end{abstract}


$\mathrm{R} A$ Annur Pungangan Kab. Subang as many as 30 students. Data collection techniques in this study used observation sheets of teacher and student activities, observation sheets of fine motor skills, and documentation. Based on research class action carried out in $\mathrm{R} A$ Annur regency. Subang, it can be concluded that the fine motor abilities of children before the application of batik making jumputan with very little criteria. As for the cycle I obtained an average value of 49.43 with a criterion of very less turns out to have increased in the second cycle obtained an average value of 74.23 with good criteria. Based on the results of the study proved that the achievement of students by using activities batik making jumps can improve children's fine motor skills.

Keywords: Child, Membatik Jumputan, fine motor

\section{Pendahuluan}

Pendidikan anak usia dini berfungsi membina, menumbuhkan, dan mengembangkan sleuruh potensi anak usia dini secara optimal sehingga terbentuk prilaku dan kemampuan dasar sesuai dengan tahap perkembangannya (Ulfa, dkk.2016). Pada keterampilan motorik kasar ini anak usia dini dapat melakukan gerakan badan secara kasar atau keras seperti merangkak, berjalan, melempar, berjongkok, dan berlari. Sedangkan pada keterampilan motorik halus ini anak usia dini dapat melakukan pengkoordinasian gerak tubuh yang dilibatkan mata dan tangan untuk dapat melakukan kegiatan yang berhubungan dengan gerakan tangan. Keterampilan motorik halus ini seperti menggenggam, memegang, merobek, menggunting, melipat, mewarnai, menggambar, menulis, menumpuk mainan, dan lainnya (Wiyani, 2014: 37:38).

Kecerdasan motorik halus setiap anak di sekolah baik dari segi kekuatan maupun ketepatan tentu tidak sama. Kondisi ini dipengaruhi oleh stimulasi dan perolehan yang dibawanya. Setiap anak di sekolah dapat mencapai tahapan perkembangan motorik halus yang optimal, asalkan mendapatkan stimulasi tepat dari guru serta lingkungan sekolahnya (Decaprio, 2015: 20).

Keterampilan motorik halus merupakan hal penting dalam masa pekembangan motorik anak usia dini (Sumantri, 2005:146). Kegiatan yang dapat meningkatkan motorik halus anak dapat dilakukan melalui berbagai macam kegiatan, seperti menyusun balok, membuat garis, bermain puzzle, menggambar, menulis, menggunting, membuat garis, melipat, membatik, mewarnai dan lain sebagainya. Setiap anak memiliki kemampuan motorik halus yang berbeda-beda tergantung dari stimulasi yang diberikan. 
Berdasarkan studi pendahuluan yang dilakukan di RA An-Nur, terdapat fenomena yang menarik untuk ditelusuri lebih mendalam. Pada kegiatan pembelajaran di kelas B RA An-Nur Pungangan Kab. Subang yang berkenaan dengan pengembangan serta peningkatan kemampuan motorik halus anak ternyata $80 \%$ dari jumlah 30 siswa dikategorikan kurang berkembang. Berdasarkan latar belakang masalah di atas, maka dapat diidentifikasi beberapa permasalahan yang muncul dalam upaya peningkatan kemampuan motorik halus anak di RA An-Nur Pungangan Kab. Subang. Oleh karena itu untuk mengatasi permasalahan tersebut perlu dilakukan penelitian yang lebih mendalam melalui kegiatan penelitian tindakan kelas. Adapun penelitian tersebut mengambil judul Upaya Meningkatkan Kemampuan Motorik Halus Anak Melalui Kegiatan Membatik Jumputan.

Adapun tujuan dalam penelitian ini dapat dirumuskan sebagai berikut: untuk mengetahui kemampuan motorik halus anak kelas B RA An-Nur Pungangan Kab. Subang sebelum menggunakan kegiatan Membatik Jumputan, untuk mengetahui Proses pembelajaran pada anak kelas B RA An-Nur Pungangan Kab. Subang ketika menggunakan metode Membatik Jumputan setiap siklus, untuk mengetahui kemampuan motorik halus anak kelas B RA An-Nur Pungangan Kab. Subang setelah menggunakan kegiatan Membatik Jumputan setiap siklus.

\section{Metodologi}

Penelitian ini menggunakan metode penelitian tindakan kelas (PTK) yang bertujuan untuk memperbaiki proses pembelajaran, dengan menggunakan pendekatan campuran. Pendekatan campuran merupakan pendekatan penelitian yang mengkombinasikan atau menggabungkan bentuk kualitatif dan bentuk kuantitatif (mixing) kedua pendekatan tersebut dalam satu penelitian (Creswell, 2013: 5). Subjek penelitian ini, melibatkan siswa kelompok B RA An-Nur tahun ajaran 2018/2019 yang berjumlah 30 siswa yang terdiri dari 17 laki-laki dan 13 perempuan.

Jenis data pada penelitian ini dibagi menjadi dua jenis yaitu data kualitatif dan data kuantitatif. Data kualitatif untuk mengetahui gambaran proses keterlaksanaan kegiatan membatik jumputan yang telah diperoleh dari lembar observasi siswa. Sedangkan kuantitatif adalah data yang berbentuk angka-angka bilangan. Teknik pengumpulan data pada penelitian ini meliputi lembar observasi aktivitas guru dan siswa, lembar observasi kemampuan motorik halus dan dokumentasi. Analisis data hasil observasi yaitu data berupa hasil observasi aktivitas guru dan siswa dianalisis menggunakan data deskriptif kualitatif 
dengan mendeskripsikan aktivitas yang dilakukan selama proses pembelajaran menggunakan kegiatan membatik jumputan, dengan menggunakan rumus:

$\mathrm{P}=$

Keterangan :

$\mathrm{P}=$ Persentase aktivitas guru dan anak

$\mathrm{f}=$ Banyaknya aktivitas guru dan anak yang muncul

$\mathrm{N}=$ Jumlah aktivitas keseluruhan

(Sudjiono, 2011:34)

dengan kriteria nilai dalam \% sebagai berikut:

$86-100=$ Sangat Baik

$76-85=$ Baik

$60-75=$ Cukup

$55-59=$ Kurang

$\leq 45=$ Kurang Sekali

(Purwanto, 2006: 103)

Analisis kemampuan motorik halus anak menggunakan pengukuran pengamatan terhadap anak dibagi menjadi empat kriteria, diantaranya BB (Belum Berkembang), MB (Mulai Berkembang), BSH (Berkembang Sesuai Harapan) dan BSB (Berkembang Sangat Baik) dengan menggunakan perumusan sebagai berikut:

Kemampuan motorik halus anak

(Hayati, 2013: 152)

Kriteria skor kemampuan motorik halus anak sebagai berikut:

$85-100=$ Sangat Baik

$65-84=$ Baik

$55-64=$ Kurang

$0-55=$ Sangat Kurang

(Aqib, 2008: 160) 


\section{Hasil dan Diskusi}

Untuk mengetahui kemampuan motorik halus anak sebelum menggunakan kegiatan membatik jumputan penulis melakukan kegiatan pratindakan berupa membatik jumputan dengan tisu berbentuk persegi. Kegiatan membatik jumputan dengan tisu tersebut menggunakan teknik menjumput dengan cara menjumput tisu lalu masukan kelereng dan diikat menggunakan karet, begitu seterusnya sesuai dengan pola yang ditentukan oleh guru. Pelaksanaan pratindakan ini menggunakan pengamatan terhadap anak diantaranya kelenturann, koordinasi mata dan tangan anak, ketepatan, dan mengekspresikan diri. kemampuan motorik halus anak dalam kegiatan membatik jumputan pada pratindakan memperoleh nilai sebesar 37,19 dengan kriteria kurang sekali Berikut dijelaskan dalam tabel 1 mengenai rekapitulasi hasil observasi anak dalam kemampuan motorik halus anak dalam kegiatan membatik jumputan pada pratindakan berdasarkan jumlah anak yang memperoleh nilai dari kriteria sangat baik sampai kurang sekali, sebagai berikut:

Tabel 1. Kemampuan Motorik Halus Anak Pratindakan

\begin{tabular}{lll}
\hline \multicolumn{1}{c}{$\begin{array}{c}\text { Tingkat } \\
\text { Keberhasilan }\end{array}$} & \multicolumn{1}{c}{$\begin{array}{c}\text { Tingkat } \\
\text { Keberhasilan }\end{array}$} & Jumlah \\
\hline Sangat Baik & $85-100$ & 0 \\
Baik & $65-84$ & 0 \\
Kurang & $55-64$ & 0 \\
Sangat Kurang & $0-54$ & 30 \\
Jumlah Anak & & 30 \\
Nilai Rata-Rata & 45,83 \\
\hline \multicolumn{3}{c}{ Sumber: Hasil penelitian, 2019 }
\end{tabular}

Kemampuan motorik halus anak pada siklus I peneliti melakukan kegiatan pembelajaran sebanyak 2 kali pertemuan, pertemuan pertama dilaksanakan pada hari Senin, 25 Februari 2019, pertemuan kedua dilaksanakan pada hari Rabu 27 Februari 2019. Pada penelitian ini jumlah anak yang mengikuti penelitian pada siklus I ini ialah sebanyak 30 orang anak. Dengan langkah perencanaan, pelaksanaan, observasi dan refleksi. Berdasarkan pada hasil perhitungan data observasi pada siklus I tindakan I memperoleh nilai rata-rata sebesar 45,83 dengan kriteria kurang sekali. Mengenai hasil rekapitulasi observasi anak berdasarkan jumlah anak yang mengalami perkembangan dalam kemampuan motorik halus anak pada kegiatan membatik jumputan:

Tabel 2. Kemampuan Motorik Halus Anak pada Kegiatan Membatik Jumputan Siklus I Tindakan Pertama 


\begin{tabular}{lll}
\hline \multicolumn{1}{c}{$\begin{array}{c}\text { Tingkat } \\
\text { Keberhasilan }\end{array}$} & \multicolumn{1}{c}{$\begin{array}{c}\text { Tingkat } \\
\text { Keberhasilan }\end{array}$} & Jumlah \\
\hline Sangat Baik & $85-100$ & 0 \\
Baik & $65-84$ & 0 \\
Kurang & $55-64$ & 2 \\
Sangat Kurang & $0-54$ & 28 \\
Jumlah Anak & & 30 \\
Nilai Rata-Rata & & 45,83 \\
\hline & Sumber: Hasil penelitian, 2019
\end{tabular}

Berdasarkan tabel di atas, diperoleh bahwa data kemampuan motorik halus anak pada kegiatan membatik jumputan pada siklus I tindakan pertama menunjukkan bahwa terdapat 28 anak dalam kriteria sangat kurang, 2 anak dalam kriteria kurang. Perolehan data ini menunjukkan bahwa adanya peningkatan dari pra siklus ke siklus I tindakan pertama walaupun nilai yang diperoleh belum maksimal, dikarenakan anak masih perlu bantuan guru dan belum ada motivasi dalam kegiatan membatik jumputan.

Pada siklus I tindakan kedua, hasil perolehan nilai kemampuan motorik halus anak melalui kegiatan membatik jumputan di RA An-Nur Pungangan Subang mengalami peningkatan. Peningkatan yang terjadi dapat dilihat pada tabel 3 sebagai berikut:

Tabel 3. Kemampuan Motorik HalusAnak pada Kegiatan Membatik Jumputan Siklus I

Tindakan Kedua

\begin{tabular}{lll}
\hline \multicolumn{1}{c}{$\begin{array}{c}\text { Tingkat } \\
\text { Keberhasilan }\end{array}$} & \multicolumn{1}{c}{$\begin{array}{c}\text { Tingkat } \\
\text { Keberhasilan }\end{array}$} & Jumlah \\
\hline Sangat Baik & $85-100$ & 0 \\
Baik & $65-84$ & 0 \\
Kurang & $55-64$ & 11 \\
Sangat Kurang & $0-54$ & 19 \\
Jumlah Anak & & 30 \\
Nilai Rata-Rata & 53,02 \\
\hline \multicolumn{3}{c}{ Sumber: Hasil penelitian, 2019 }
\end{tabular}

Berdasarkan tabel di atas, diperoleh bahwa data kemampuan motorik halus anak pada kegiatan membatik jumputan pada siklus I tindakan kedua menunjukkan bahwa terdapat 19 anak dalam kriteria kurang sekali dan 11 anak dalam kriteria kurang. Perolehan data ini menunjukkan bahwa adanya peningkatan kemampuan anak yaitu pada kriteria kurang sekali terdapat 19 anak yang pada awalnya 28 anak dan kriteria kurang terdapat 11 anak yang pada awalnya 2 anak. Berikut dijelaskan pada tabel 4 mengenai hasil rata-rata kemampuan kognitif anak pada pembelajaran sains pada siklus I tindakan pertama dan kedua: 
Tabel 4. Rata-rata Hasil Observasi Kemampuan Motorik Halus Anak pada Kegiatan Membatik Jumputan pada Siklus I

\begin{tabular}{lll}
\hline \multicolumn{1}{c}{ No } & \multicolumn{1}{c}{ Tingkat } & Nilai Rata-rata \\
\hline 1 & Tindakan Pertama & 45,83 \\
2 & Tindakan Kedua & 53,02 \\
Nilaia Rata-rata & & 49,43
\end{tabular}

Sumber: Hasil penelitian, 2019

Berdasarkan tabel di atas, diperoleh nilai rata-rata pada siklus I sebesar 49,43 dengan kriteria sangat kurang. Maka dilakukan peningkatan pembelajaran untuk membantu kemampuan motorik halus anak pada kegiatan membatik jumputan pada siklus II.

Pada siklus II kemampuan motorik halus anak pada kegiatan membatik jumputan terdiri dari dua tindakan. Tindakan pertama dilaksanakan pada tanggal 5 Maret 2019 dan tindakan kedua pada tanggal 6 Maret 2019. Adapun hasil penelitian mengenai kemampuan motorik halus anak pada kegiatan membatik jumputan di siklus II tindakan pertama 68,55 dengan kriteria cukup. Berdasarkan jumlah anak yang mengalami perkembangan dalam kemampuan motorik halus pada kegiatan membatik jumputan:

Tabel 5. Kemampuan Motorik HalusAnak pada Kegiatan Membatik Jumputan Siklus II Tindakan Pertama

\begin{tabular}{lll}
\hline \multicolumn{1}{c}{$\begin{array}{c}\text { Tingkat } \\
\text { Keberhasilan }\end{array}$} & \multicolumn{1}{c}{$\begin{array}{c}\text { Tingkat } \\
\text { Keberhasilan }\end{array}$} & Jumlah \\
\hline Sangat Baik & $85-100$ & 0 \\
Baik & $65-84$ & 23 \\
Kurang & $55-64$ & 7 \\
Sangat Kurang & $0-54$ & 0 \\
Jumlah Anak & & 30 \\
Nilai Rata-Rata & 68,55 \\
\hline \multicolumn{3}{c}{ Sumber: Hasil penelitian, 2019 }
\end{tabular}

Berdasarkan tabel di atas, diperoleh bahwa data kemampuan motorik halus anak pada kegiatan membatik jumputan pada siklus II tindakan pertama menunjukkan bahwa terdapat 23 anak dalam kriteria baik dan 7 anak dalam kriteria kurang. Perolehan data ini menunjukkan bahwa adanya peningkatan kemampuan motorik halus pada kegiatan membatik jumputan.

Pada siklus II tindakan kedua, hasil perolehan nilai kemampuan motorik halus anak pada kegiatan membatik jumputan mengalami peningkatan. Nilai rata-rata seluruh anak pada siklus II tindakan kedua sebesar 79,90 dengan kriteriasangat baik, perolehan ini 
menunjukkan bahwa terjadi peningkatan yang lebih baik dibandingkan tindakan sebelumnya. Berikut dijelaskan pada tabel 4.20 mengenai hasil rekapitulasi observasi berdasarkan jumlah anakmengalami perkembangan dalam kemampuan motorik halus anak pada kegiatan membatik jumputan:

Tabel 6. Kemampuan Motorik HalusAnak pada Kegiatan Membatik Jumputan Siklus II Tindakan Kedua

\begin{tabular}{lll}
\hline \multicolumn{1}{c}{$\begin{array}{c}\text { Tingkat } \\
\text { Keberhasilan }\end{array}$} & \multicolumn{1}{c}{$\begin{array}{c}\text { Tingkat } \\
\text { Keberhasilan }\end{array}$} & Jumlah \\
\hline Sangat Baik & $85-100$ & 3 \\
Baik & $65-84$ & 27 \\
Kurang & $55-64$ & 0 \\
Sangat Kurang & $0-54$ & 0 \\
Jumlah Anak & & 30 \\
Nilai Rata-Rata & 79,90 \\
\hline \multicolumn{3}{c}{ Sumber: Hasil penelitian, 2019 }
\end{tabular}

Berdasarkan tabel di atas, diperoleh data bahwa pada siklus II tindakan kedua kemampuan motorik halus anak pada kegiatan membatik jumputan mengalami peningkatan menjadi lebih baik, terlihat bahwa sudah tidak ada anak dalam kriteria kurang dan sangat kurang. Pada siklus II tindakan kedua anak sudah ada pada kriteria baik dengan jumlah 27 anak dan kriteria sangat baik dengan jumlah 3 anak. Berikut dijelaskan pada tabel 7 mengenai hasil rata-rata kemampuan motorik halus anak pada kegiatan membatik jumputan pada siklus II tindakan pertama dan kedua:

Tabel 7. Rata-rata Hasil Observasi Kemampuan Motorik Halus Anak pada Kegiatan Membatik Jumputan pada Siklus II

\begin{tabular}{|c|c|c|}
\hline No & Tingkat & Nilai Rata- rata \\
\hline 1 & Tindakan Pertama & 68,55 \\
\hline 2 & Tindakan Kedua & 79,90 \\
\hline
\end{tabular}

Nilai rata-rata

Sumber: Hasil penelitian, 2019

Berdasarkan tabel di atas, diperoleh nilai rata-rata pada siklus II sebesar 74,23 dengan kriteria baik. Dari data yang diperoleh pada pra siklus, siklus I dan siklus II terdapat peningkatan yang signifikan dari tiap siklusnya. 


\section{Pembahasan}

Berdasarkan hasil observasi pra siklus mengenai kemampuan motorik halus anak pada kegiatan membatik jumputan diperoleh data bahwa 30 anak dalam kriteria sangat kurang dengan nilai rata-rata diperoleh sebesar 37,19 dengan kriteria sangat kurang. Keadaan ini menunjukkan bahwa kemampuan motorik halus anak pada kegiatan membatik jumputan sangat kurang. Setelah dilakukan observasi dapat dilihat bahwa kurangnya motivasi anak untuk melakukan kegiatan ditandai dengan perilaku anak tidak tertarik untuk mengerjakan kegiatan yang diberikan, anak lebih tertarik untuk bermain dengan temannya ketika kegiatan dimulai, ketika anak tidak tertarik untuk mengerjakan kegiatan yang diberikan, guru selalu memberi motivasi anak agar anak melakukan kegiatan tersebut. Guru memberikan motivasi dengan motivasi kata-kata ajakan dan semangat untuk menyelesaikan tugas yang sudah diberikan pada anak.

Berdasarkan hasil observasi kemampuan motorik halus anak pada kegiatan membatik jumputan pada siklus I tindakan pertama diperoleh data bahwa terdapat 28 anak dalam kriteria sangat kurang dan 2 anak dalam kriteria kurang. Pada siklus I tindakan kedua diperoleh data bahwa terdapat 19 anak dalam kriteria sangat kurang dan 11 anak dalam kriteria kurang. Perolehan nilai rata-rata pada siklus I tindakan pertama sebesar 45,83 dan tindakan kedua sebesar 43,02, maka nilai rata-rata pada siklus I sebesar 49,43 dengan kriteria sangat kurang.

Pada siklus II tindakan pertama kemampuan motorik halus anak pada kegiatan membatik jumputan menunjukkan peningkatan, diperoleh data bahwa 7 anak dalam kriteria kurang dan 23 anak dalam kriteria baik. Pada siklus II tindakan kedua kemampuan kemampuan motorik halus anak pada kegiatan membatik jumputan menunjukkan peningkatan yang lebih baik, diperoleh data bahwa sudah tidak ada anak dalam kriteria sangat kurang dan kurang, 27 anak dalam kriteria baik dan 3 anak dalam kriteria sangat baik.

Dilihat dari beberapa siklus yang telah dilakukan terjadi peningkatan yang signifikan terhadap motorik halus anak dengan kegiatan membatik jumputtan. Membatik jumputan sendiri menurut Murtono (2007: 13) adalah batik yang proses pembuatannya berbeda dengan batik tulis atau batik cap, yaitu dengan cara mengikat dibeberapa bagian kain yang ingin diberi motif. Sedangkan menurut Herni (2007: 40) membatik jumputan pada 
dasarnya adalah proses pencelupan yaitu, sebagian kain diikat rapat menurut pola tertentu sebelum dilakukan pencelupan dengan zat warna.

Membatik jumputan merupakan salah satu strategi yang dapat dilakukan untuk meningkatkan kemampuan motorik halus anak. Kemampuan motorik halus fokus pada kemampuan koordinasi tangan dan mata (Masganti, 2017: 18). Kemampuan motorik halus merupakan salah satu aspek perkembangan anak yang harus dioptimalkan perkembangannya. Motorik halus didefinisikan sebagai keterampilan yang memerlukan kemampuan untuk mengkoordinasikan atau mengatur otot-otot kecil/halus. Misalnya berkaitan dengan aktivitas dari gerakan mata dan tangan yang mewakili bagian yang penting dalam perkembangan motorik (Rahyubi, 2012: 222)

Keterampilan motorik halus berperan penting dalam kehidupan anak. Dalam kehidupan sehari-hari anak tidak lepas dari kegiatan motorik halus. Keterampilan motorik halus menjadi salah satu keterampilan yang dikembangkan di pendidikan anak usia dini. Keterampilan dapat diuraikan dengan kata otomatik, cepat, dan akurat. Keterampilan yang dipelajari dengan baik akan berkembang menjadi kebiasaan (Hurlock, 1978: 154). Untuk mencapai keterampilan motorik halus yang baik maka pendidik harus memberikan stimulasi kepada anak guna menunjang pencapaian keterampilan motorik halus yang optimal. Individu yang mendapat stimulasi yang terarah dan teratur akan lebih cepat mempelajari sesuatu karena lebih cepat berkembang dibandingkan individu yang tidak banyak mendapatkan stimulasi (Izzaty, dkk. 2008: 14).

Berdasarkan data hasil penelitian, keterampilan motorik halus setiap anak mengalami peningkatan secara bertahap pada tiap siklusnya. Hasil tersebut menegaskan bahwa kegiatan membatik jumputan dapat dijadikan salah satu alternatif bagi guru untuk menstimulasi kemampuan motorik halus anak didiknya.

\section{Penutup}

Berdasarkan hasil penelitian tindakan kelas yang dilaksanakan di kelas B RA AnNur Pungangan Kab. Subang, maka dapat disimpulkan: 
Kemampuan motorik halus anak diperoleh rata-rata 37,19\%. Hasil tersebut menunjukkan bahwa kemampuan motorik halus anak kurang sekali. kemampuan motorik halus anak setelah diterapkan kegiatan membatik jumputan pada siklus I diperoleh nilai rata-rata 49,43 dengan kriteria kurang sekali dan pada siklus II diperoleh nilai rata-rata sebesar 74,23 dengan kriteria baik.

Berdasarkan hasil pembahasan dan kesimpulan dapat dikemukakan saransaransebagai berikut: Berdasarkan hasil penelitian pra siklus terbukti kemampuan motorik halus anak dikategorikan sangat kurang. Maka dengan itu guru atau pihak lain perlu melakukan perbaikan dengan tujuan untuk meningkatkan kemampuan motorik halus anak. Berdasarkan hasil penelitian selama proses pembelajaran berlangsung terbukti bahwa metode Membatik Jumputan dapat meningkatkan kemampuan motorik halus anak. Oleh karena itu kegiatan membatik jumputan dapat direkomendasikan sebagai salah satu aktivitas alternatif dalam upaya meningkatkan kemampuan motorik halus anak. Berdasrkan hasil penelitian terbukti bahwa ketercapaian belajar siswa, dengan menerapkan metode Membatik Jumputan dapat meningkatkan kemampuan motorik halus anak. Berdasarkan hal tersebut, guru dapat mempertimbangkan bahwa kegiatan membatik jumputan merupakan salah satu solusi alternatif untuk menggali serta mengembangkan kemampuan motorik halus anak. Kemampuan motorik halus anak merupakan aspek yang sangat penting bagi perkembangan anak, oleh sebab itu peneliti selanjutnya diharapkan dapat membuat penelitian mengenai keterampilan motorik halus anak melalui berbagai kegiatan atau media yang lain agar lebih menarik bagi anak.

\section{Daftar Pustaka}

Aqib, Zainal. 2008. Penelitian Tindakan Kelas. Bandung: CV. Yarma Widya.

Creswell W, Jhon. 2013. Research Design. Yogyakarta: Pustaka Pelajar.

Hayati, Tuti. 2013: Evaluasi Pembelajaran. Bandung: CV. Insan Mandiri.

Herni Kusantati. Dkk. 2007. Keterampilan. Bandung: CV. Insan Mandiri.

Hurlock, E. B. 1978. Perkembangan Anak. Jakarta: Erlangga.

Masganti. 2017. Psikologi Perkembangan Anak Usia Dini. Medan: Perdana Publising.

Murtono Sri. Dkk. 2007. Seni Budaya dan Keterampilan. Bogor: Yudhistira. 
Wiyani, Novan Ardy. 2014. Psikologi Perkembangan Anak Usia Dini. Penerbit Gava Media: Yogyakarta.

Purwanto. 2006. Statistika Untuk Penelitian. Yogyakarta: Pustaka Pelajar.

Rahyubi, Heri. 2012. Teori-teori Belajar dan Aplikasi Pembelajaran Motorik. Majalengka: Referens.

Richard decaprio. 2013. Aplikasi Teori Pembelajaran Motorik di Sekolah. Jogjakarta: DIVA Press.

Rita Eka Izzaty, Siti Partini Suadirman, Yulia Ayriza, Purwandari, Hiryanto \& Rosita E. Kusumaryani. 2008. Perkembangan Peserta Didik. Yogyakarta: UNY Press.

Sudjiyono. (2011). Statistika untuk penelitian. Bandung: Alfabeta.

Sumantri, M. S. 2005. Model Pengembangan Keterampilan Motorik Anak Usia Din. Jakarta: Departemen Pendidikan Nasional.

Windri Rosania Ulfa. 2016. Peningkatan Kemampuan Motorik Halus Melalui Kegiatan Membatik Jumputan. Jember. 